Article

\title{
Selective Attachment of Leptospirillum ferrooxidans for Separation of Chalcopyrite and Pyrite through Bio-Flotation
}

\author{
Belinda Bleeze, Jing Zhao and Sarah L. Harmer* \\ Centre for Nanoscale Science and Engineering, College of Science and Engineering, Flinders University, \\ GPO Box 2100, Adelaide 5001, South Australia, Australia; blee0008@flinders.edu.au (B.B.); \\ jing.zhao@flinders.edu.au (J.Z.) \\ * Correspondence: sarah.harmer@flinders.edu.au; Tel.: +61-088-201-5338
}

Received: 31 January 2018; Accepted: 1 February 2018; Published: 27 February 2018

\begin{abstract}
The replacement of depressants used in sulfide mineral beneficiation, with bacteria and their metabolites, promises to reduce the environmental impact left by the mining industry. In this study, the attachment of Leptospirillum ferrooxidans, L.f, to chalcopyrite and pyrite was investigated through Scanning Electron Microscopy (SEM). The impact of selective attachment, bacterial growth conditions, and extracellular polymeric substances (EPS) was investigated through bio-flotation. L.f exhibits selective attachment to pyrite between $0 \mathrm{~h}$ and $168 \mathrm{~h}$ exposure via an indirect contact mechanism. Separation of chalcopyrite from pyrite was achieved through exposing the minerals for $72 \mathrm{~h}$ with an L.f culture grown on either $\mathrm{HH}$ media, chalcopyrite, or pyrite. The results produced 80.4, 43.4 , and $47.4 \%$ recovery of chalcopyrite, respectively. However, EPS supernatant extracted from L.f grown on chalcopyrite, conditioned for $48 \mathrm{~h}$, provided the best separation efficiency by the selective depression of pyrite resulting in $95.8 \% \mathrm{Cu}$ recovery. Polysaccharide-rich EPS selectively attaches to pyrite within $48 \mathrm{~h}$, depressing its floatability and ensuring successful separation with a PIPX collector.
\end{abstract}

Keywords: Leptospirillum ferrooxidans; bio-flotation; selective attachment; chalcopyrite; pyrite

\section{Introduction}

Chalcopyrite $\left(\mathrm{CuFeS}_{2}\right)$ is the most abundant copper mineral and is currently the world's primary source of copper [1]. Chalcopyrite is commonly associated with other sulfide minerals, including pyrite $\left(\mathrm{FeS}_{2}\right)[2,3]$, thus separation and refinement are key processes in copper recovery. Pyrite is the most abundant sulfide mineral in the Earth's crust; having no overall commercial value it is regarded as a gangue mineral. The most common method of separation for sulfide minerals is froth flotation [1], a physicochemical technique which utilizes the difference in surface chemistry and hydrophobicity of the minerals. The addition of highly selective inorganic chemicals, such as xanthate and cyanides, enhances the separation efficiency [1,2]. These chemicals and sulfide mineral processing are known to have a detrimental effect on the environment [4]. Beneficiation of low grade ore is driven by the depletion of high grade ores and an increase in the demand of material $[5,6]$. Low grade ores have a higher mineralogical complexity than high grade ores, increasing the difficulty of separation [7]. Consequently, the use of bacteria in minerals processing has been investigated and is well established; the main focus concerning leaching, the environmental impact and economic viability of minerals processing [5]. Bio-flotation has more recently been investigated for low grade ore beneficiation and focuses on replacing traditional reagents with bacteria and their metabolic products through the pioneering work of Natarajan, Subramanian, and Rao et al. [2-4,7-14].

Selective modification of the surface physico-chemical properties of mineral surfaces is crucial for successful separation of pyrite and chalcopyrite. Attachment of cells to a solid surface is complex 
and dependent on a number of chemical and physical properties of both the cell and the surface. These properties include: the type and motility of the bacteria; cell wall chemistry; extracellular polymeric substances (EPS); surface chemistry; the charge of both the surface and the bacteria; ionic strength and $\mathrm{pH}$ of solution; cell elasticity; and surface roughness [15]. Three potential mechanisms have been identified for microbe-mineral interactions, these are: direct contact, indirect contact, and indirect non-contact $[7,16,17]$. Recent research suggests that each of these mechanisms are mediated by the bacterial biopolymers; in the case of direct and indirect contact mechanisms the biopolymers assist in irreversible binding of the cells $[5,11,15,18-20]$. These biopolymers include extracellular polymeric substances (EPS). EPS is a complex system of biopolymers and is comprised of proteins, polysaccharides, lipids, humic substances, and uronic acid [7,11,15,18,21,22]. The composition and characteristics are found to change depending on the bacterial strain and the growth conditions, with the microbes adapting their EPS to suit their geochemical environment [11,18,22-27]. Proteins are known to increase the hydrophobicity, whilst the polysaccharide components are known to induce hydrophilicity changes [7]. It is proposed that the polysaccharides' hydroxyl groups in the EPS complex with the metal ions at the mineral surface $[10,28]$. EPS from Gram negative, mesophilic bacteria are expected to have higher concentrations of polysaccharides [11,18].

Bio-leaching of sulfide mineral systems have been thoroughly investigated, with the focus on the mesophilic iron and sulfur oxidizing bio-leach microbes Acidithiobacillus ferrooxidans (A.f, formally T. ferrooxidans), Acidithiobacillus thiooxidans (A.t), and Leptospirillum ferrooxidans (L.f) a chemolitoautotroph with the ability to oxidise iron $[7,11-13,17,20,26,29-31]$. The use of $A . f$ and $L . f$ for application in bio-flotation has been investigated more recently and focuses on the selective attachment and EPS expression. A.f has been investigated for its effect on iron sulfide flotation due to its ability to oxidize iron and inorganic sulfur compounds [4]. Bio-flotation studies using A.f and its EPS have included the separation of pyrite (Py) from chalcopyrite (Cp) and arsenopyrite (Aspy) $[3,9,19,32]$. These studies suggests irreversible attachment of $A$.f to the Py surface occurs within minutes [32], while attachment to Cp was observed after 12 days allowing for successful separation [23]. Enhanced absorption of cells on Py resulted in selective depression of Py over Cp and Aspy and greater dissolution observed in the presence of active cells with EPS [3,9,11,24]. Investigations into the effect of EPS on the bio-modulation of Py and Cp found cells with EPS resulted in a lower recovery than the free extracted EPS alone [7].

L.f has been used in iron sulfide mineral studies as their iron oxidizing capabilities produces a favorability in binding to iron [33]. The oxidation state of iron in the minerals may contribute to the selective attachment of L.f as iron exists as $\mathrm{Fe}^{2+}$ in $\mathrm{Py}$ and $\mathrm{Fe}^{3+}$ in $\mathrm{Cp}[34,35]$. The bio-modulation of pyrite, chalcopyrite, sphalerite, and pyrrhotite (Po) by L.f and metabolites has been investigated with conflicting results $[33,36]$. These studies suggest $L . f$ and/or EPS has a weak depressive effect on Po and enhances $\mathrm{Cp}$ flotability [33]. While Vilinska and Rao [36] reported a depressive effect on Cp in a $\mathrm{Cp} /$ Py mixed system. The presence of the L.f was found to have greater impact on $\mathrm{Cp}$ than Py, due to the increased amount of surface defects, and the increased availability of iron on the surface leading to a greater cell adsorption. Cell adsorption was determined through counts in solution over exposure time, with the difference in counts given as the number of adsorbed cells [36]. Without visualization of active cells and EPS on the surface it is difficult to determine the cause of surface chemistry changes as solution counts do not include dead or inactive cells. As EPS is known to mediate the microbe-mineral interaction, cell counts are not enough to determine the impact of the cells alone.

The implications of L.f cells and the interaction of their extracted EPS with Py and Cp is yet to be completely understood. Although previous studies have investigated the $\mathrm{Cp} / \mathrm{Py}$ system with biological influences at various exposure conditions such as cell concentration, $\mathrm{pH}$, and collector concentration; the effect of different exposure times, visualization of cells showing selective attachment and biofilm/EPS attachment has not specifically been investigated $[3,7,36]$. This study addresses the use of a single mesophilic, bio-leach microbe (Leptospirillum ferrooxidans) and the extracted EPS for the selective flotation of $\mathrm{Cp}$ from Py. The purpose of this study is to determine the individual effect of (i) 
the bacterial cell; (ii) the EPS; and (iii) different growth conditions; to optimize the separation of $\mathrm{Cp}$ and Py with bio-flotation.

\section{Materials and Methods}

\subsection{Mineral Samples}

Pure mineral samples of Py (Peru) and Cp (Moonta Mines, Australia), were sourced from GeoDiscovery (The Willyama Group, Broken Hill Block, NSW, Australia). Each sample was characterized using Quantitative Evaluation on Minerals by Scanning electron microscopy (QEMSCAN, FEI, Hillsboro, OR, USA) to confirm their composition and purity. The results indicated that the Py sample was $88 \%$ pyrite, $12 \%$ pyrrhotite, while the Cp sample had approximately $17 \%$ bornite present [37].

Mineral samples were ground using a rubber lined Galigher mill in deionized water, with steel rods as the grinding media. The mineral samples were ground to a $\mathrm{D}_{80}$ of $50 \mu \mathrm{m}$ and stored at $-80{ }^{\circ} \mathrm{C}$ in sealed containers purged with nitrogen. The mineral samples were wet sieved to a size fraction of 38 to $75 \mu \mathrm{m}$.

\subsection{Bacterial Culture and Adjustment to Mineral}

L.f culture was obtained from DSMZ (DSM 2705, Braunschweig, Germany) and cultured as a 5\% inoculation in modified Leptospirillum $\mathrm{HH}$ media $\left(\left(\mathrm{NH}_{4}\right)_{2} \mathrm{SO}_{4}, \mathrm{MgCl}_{2} \cdot 6 \mathrm{H}_{2} \mathrm{O}, \mathrm{KH}_{2} \mathrm{PO}_{4}, \mathrm{CaCl}_{2} \cdot 2 \mathrm{H}_{2} \mathrm{O}\right)$ at $\mathrm{pH} 1.8$, and $30^{\circ} \mathrm{C}$ on a rotary shaker maintaining $155 \mathrm{rpm}$. An iron (II) sulfate heptahydrate solution is added to base cultures as a soluble energy source. Cultures were inoculated at late exponential phase, with base cultures on a culture cycle of 4 days and mineral cultures on a cycle of 21 days. Mineral cultures were inoculated as a $10 \%$ inoculate with 20 grams of $35-75 \mu \mathrm{m}$ mineral (Py or Cp) in Leptospirillum $\mathrm{HH}$ medium ( $\mathrm{pH}$ 1.8) that excluded iron (II) sulfate hetahydrate solution.

Culture growth was monitored through cell counts using a hemocytometer at 40 times magnification [12,38]. Ferrous ion concentration of base cultures was monitored through oxidation-reduction titrations with cerium sulfate and 1,10-phelanthroline indicator.

\section{Free EPS}

Cultures were harvested at late exponential phase. Mineral particles were removed using a $5 \mu \mathrm{m}$ Millipore SMWP mixed cellulose membrane and vacuum filtration. The filtrate was centrifuged at $15,000 \mathrm{rpm}$ to pellet cells. The supernatant was decanted and filtered through a $0.2 \mu \mathrm{m}$ Isopore hydrophilic membrane to remove any remaining cells producing the free EPS supernatant solution. The cell pellet was re-suspended in HH media to produce EPS-free cell culture.

\subsection{Scanning Electron Microscopy (SEM)}

Pure mineral sections were shaped using different grades of silicon carbide sandpaper and polished using diamond paste $(1 \mu \mathrm{m}$ and $0.25 \mu \mathrm{m})$ with a Trident polishing cloth. The surface of the mineral sections was cleaned through sonication in Milli-Q water and sterilized using ultraviolet light.

Cell exposures occurred at a total cell concentration of $1.5 \times 10^{7}$ cells $/ \mathrm{mL}$ of $L . f$ cultures adapted to the respective mineral and incubated at $30{ }^{\circ} \mathrm{C}$ on a rotary shaker maintaining $155 \mathrm{rpm}$. Samples were removed and preserved in 3\% glutaraldehyde fixative solution. Samples were removed and washed with PBS buffer (phosphate buffered saline containing 4\% sucrose) before being saturated with $2 \%$ osmium tetroxide. Dehydration of samples occurred through a step-wise dehydration process using a series of ethanol concentrations and completed with 1-1-3-3-3 Hexamethyldisilazane (HMDS), with samples left to air-dry. Sputter coating of platinum $(\sim 2 \mu \mathrm{m})$ occurred before imaging with a Philips XL30 Field Emission Scanning Electron Microscope (Philips, Amsterdam, Netherlands).

Images were obtained using both the secondary electron (SE) mode and the back scattered electron (BSE) mode, to detect bacterial attachment and topographical changes with high resolution. Energy 
Dispersive Analysis by X-ray (EDAX,) was used to analyse and quantify the chemical composition of both the mineral and the components adhered to the surface. All images were taken with an accelerating voltage of $20 \mathrm{kV}$, spot size of 4, and a working distance of $10 \mathrm{~mm}$. To assess the cell and EPS density on the mineral surface, SEM images were used to obtain cell counts using ImageJ program. Counts were conducted on six samples for each timeframe. Statistical analysis was carried out using a Student t-distribution with $95 \%$ probability.

\subsection{Micro Flotation Tests}

Bio-flotation tests were carried out using a modified Hallimond tube for 5 min with a flow rate of $0.4 \mathrm{~L} / \mathrm{min}^{-1}$ of industrial grade compressed air. Optimal flow rate was determined through baseline recovery tests. Both the floated fraction and the tailings were collected and analysed through quantitative X-Ray Diffraction (XRD) and recoveries were calculated. A sample size of $1 \mathrm{~g}$ was used, with mixed samples being a 1:1 synthetic mix of Py:Cp. Control flotation tests $(0 \mathrm{~h})$ were conducted without preconditioning of the sample for both Milli-Q adjusted to $\mathrm{pH} 9$ using $\mathrm{NaOH}$ (will be referred as M.Q in this study) and modified Leptospirillum $\mathrm{HH}$ medium at $\mathrm{pH} 1.8$ (will be referred as $\mathrm{HH}$ media in this study). Preconditioning of the samples was conducted in a $50 \mathrm{~mL}$ Erlenmeyer flask and stirred at $155 \mathrm{rpm}$ and $30^{\circ} \mathrm{C}$ for the duration of the exposure. For bacterial exposures a total cell concentration of $1.5 \times 10^{7}$ cells $/ \mathrm{mL}$ was used.

Conditioning for flotation tests were characterized into three groups to explore the effects of individual variables on $\mathrm{Cp}$ recovery. These categories are: baseline, growth conditions, and EPS conditions. Flotation tests were conducted as collectorless flotation tests and in the presence of potassium isopropyl xanthate (PIPX) collector $\left(10^{-4} \mathrm{M}\right)$. For a reference to industrial processes, baseline flotation tests were also completed in the presence of sodium bisulfite $\left(\mathrm{NaHSO}_{3}\right)$ depressant $\left(1.9 \times 10^{-3} \mathrm{moL}^{-1}\right)$ [39]. $\mathrm{NaHSO}_{3}$ is used in Py and $\mathrm{Cp}$ separation as it can enhance the selectivity of the collector [40]. All flotation tests were conducted at ambient temperatures. A summary of flotation test conditions is provided in Table 1.

Table 1. Conditioning of samples at an exposure time of $24 \mathrm{~h}, 48 \mathrm{~h}$, and $72 \mathrm{~h}$.

\begin{tabular}{cc}
\hline Baseline & Conditions \\
\hline \multirow{3}{*}{ Food Source } & M.Q Water adjusted to $\mathrm{pH}$ H with $\mathrm{NaOH}$ \\
& H.f grown in $\mathrm{HH}$ Media $\left(\mathrm{Fe}^{2+}\right)$ \\
L.f grown on $\mathrm{Py}$ \\
L.f grown on $\mathrm{Cp}$ \\
\hline EPS & EPS supernatant extracted from $L . f$ grown on Py \\
& EPS supernatant extracted from $L . f$ grown on $\mathrm{Cp}$ \\
EPS-Free Cells $(L . f$ grown on Py)
\end{tabular}

X-Ray Diffraction (XRD) Analysis

Flotation test fractions were analysed by XRD using a Huber Guinier Image Plate G670 at the South Australian Museum (Adelaide, Australia). Samples were ground to less than $50 \mu \mathrm{m}$ and were transferred onto the Mylar X-ray film window of the analysis disc and were exposed to a Co $\mathrm{K} \alpha_{1}[\lambda=1.78892 \AA]$ radiation source. The quantitative analysis was determined by Rietveld quantitative phase analysis (QPA) of powder X-ray diffraction data using the program of TOPAS [41]. A pseudo-Voigt function and sixth-order Chebychev polynomial were used to model the peak shapes and the background, respectively. For each diffractogram, the zero shift and scale factors for chalcopyrite (ICSD database No. 94554) and pyrite (No. 15012) were refined. 


\section{Results}

\subsection{Leptospirillum Ferrooxidans Growth}

The growth cycle of the L.f in $\mathrm{HH}$ media was monitored over $96 \mathrm{~h}$ through bacterial cell counts and ferrous iron concentration in solution, the results of which are shown in Figure 1a. The rapid decrease in ferrous iron concentration corresponds to the rapid increase of the exponential phase of the culture, confirming the ability of the culture to oxidise ferrous iron.

The growth cycle of L.f adjusted to Py and Cp were monitored through cell counts for $504 \mathrm{~h}$ (21 days) with the growth curves shown in Figure 1b. The growth on HH media is rapid with the lag phase lasting only $\mathrm{h}$, while the cultures grown on mineral have a lag phase that lasts $24 \mathrm{~h}$ or more. The exponential phase of L.f adjusted to pyrite occurs rapidly, similar to that of the HH media. The difference in culture growth between the Py and Cp cultures indicates a better adaption to Py than $\mathrm{Cp}$, resulting in a higher concentration of cells in the pyrite culture throughout the entire duration of the cycle. Although the Py culture contains a higher cell concentration than the Cp culture, the L.f on $\mathrm{HH}$ media has a far greater cell concentration of all growth conditions. There are two theories for the slower growth rate of L.f adjusted to Cp, these are: (a) Lack of nutrients for the cell. Iron in Cp exists as $\mathrm{Fe}^{3+}$, limiting the nutrients available for cell growth and replication; and (b), copper toxicity [42].
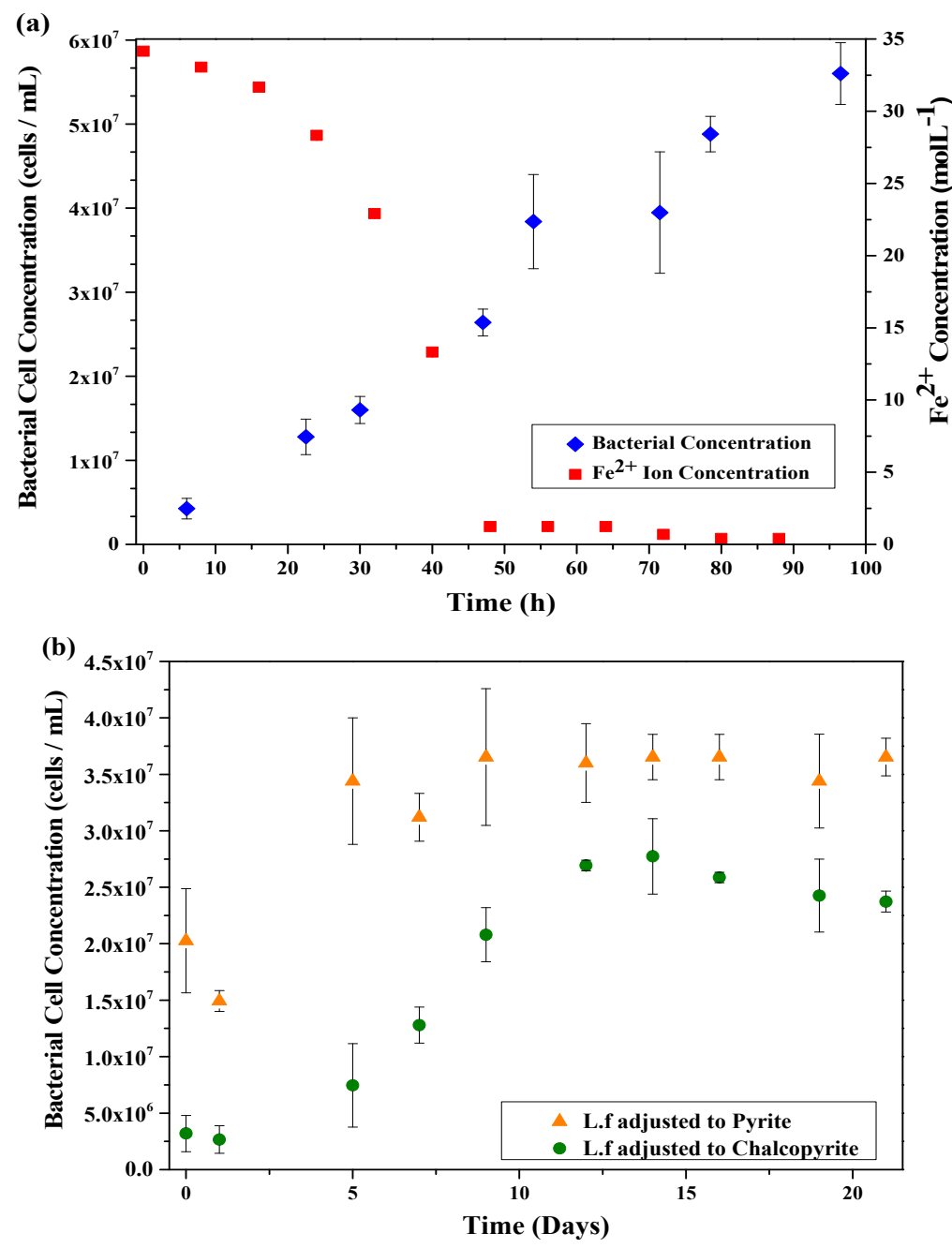

Figure 1. Bacterial growth curves of (a) L.f grown on HH media with iron (II) sulfate and (b) L.f grown on Py and Cp. 


\subsection{SEM Analysis}

Bacterial attachment to pure mineral sections were analysed at exposure times of 2, 24, 48, 72 , and $168 \mathrm{~h}$ using SEM. While previous studies have conducted adsorption studies on mineral particles [3], this method allows visual representation of cell presence, attachment, and density over time. Attachment of the L.f was observed to occur rapidly to the Py in comparison to the Cp, with surface roughening, pitting, and morphology changes appearing at a greater rate on the Py surface than the Cp surface, as shown in Figures 2-4. Media salt precipitation was present in all samples, although it was predominantly observed on the $\mathrm{Cp}$ with the occurrence increasing with exposure time.

Bacterial exposure to Py mineral surface at 2, 24, 48, and $72 \mathrm{~h}$ (Figure 2) demonstrates the rapid rate at which the cells irreversibly attach to the mineral surface. The number of cells observed on the surface increases with exposure time as shown in Table 2. Initially, the cell attachment is observed around preexisting voids of the surface. The surface roughness and occurrence of surface imperfections increases over time. This is a result of both dissolution and sedimentation/precipitation on the surface. The surface roughness effects from dissolution are a result of early stages of bacterial or chemical leaching, while the sediment observed is a mixture of precipitated salts from the growth medium and early stages of EPS/biofilm formation. The EPS structure seen in Figure 2c has previously been described as a macromolecular "honey comb" structure [21].

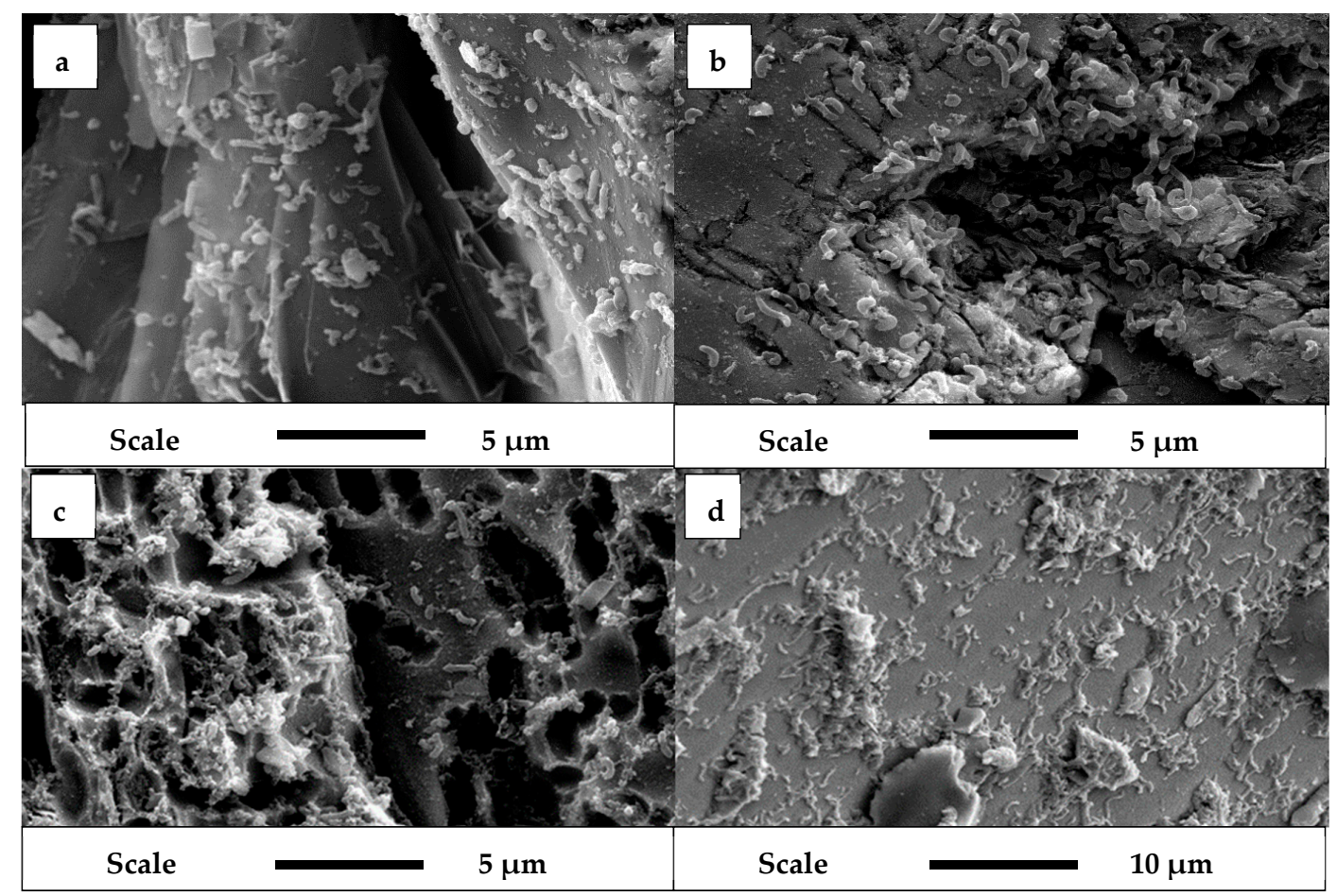

Figure 2. SEM image of Py mineral surface exposed to L.f at (a) 2 h, (b) 24 h, (c) 48 h, and (d) 72 h at a magnification of $1000 \times(\mathbf{a}-\mathbf{c})$ and $6500 \times(\mathbf{d})$.

L.f exposed to Cp surface at 2, 24, 48, and $72 \mathrm{~h}$ (Figure 3) does not show any visible signs of cell attachment. However, there is a surface roughening effect though precipitation of media salts which increases over time. In comparison to the Py samples, there is a distinct lack of voids and EPS/biofilm formation on the surface.

The speckled appearance of the chalcopyrite surface when exposed to L.f has been detected previously in a study by Usher, et al. [43]. It was noted that the speckled appearance and the debris on the surface is attributed to media crystallization and settling on the surface, and cell products such as polyphosphate (polyP) [43]. 


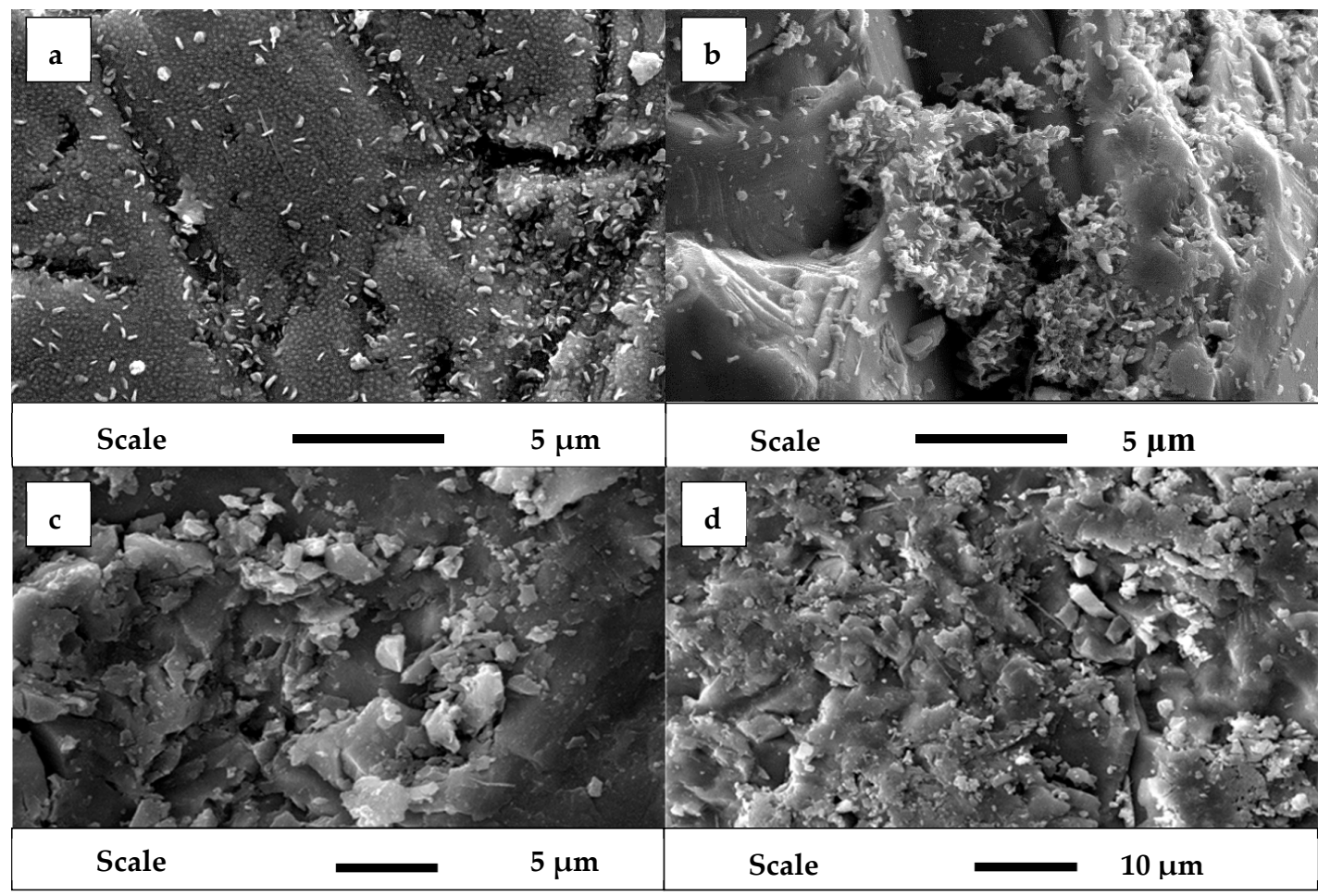

Figure 3. SEM image of Cp surface exposed to L.f at (a) $2 \mathrm{~h}$, (b) $24 \mathrm{~h}$, (c) $48 \mathrm{~h}$, and (d) $72 \mathrm{~h}$ at a magnification of $1000 \times(\mathbf{a}), 1200 \times(\mathbf{b}), 1500 \times(\mathbf{c})$, and $6500 \times(\mathbf{d})$.

Bacterial exposure to Py and Cp at $168 \mathrm{~h}$ (Figure 4) increases the surface roughness of the minerals. The Py surface has an increase in pitting and EPS/biofilm formation, while the Cp surface shows an increase in salt precipitation. Cell attachment is now observed on both Py and Cp surfaces, indicating that at $168 \mathrm{~h}$ exposure there is no selective attachment.

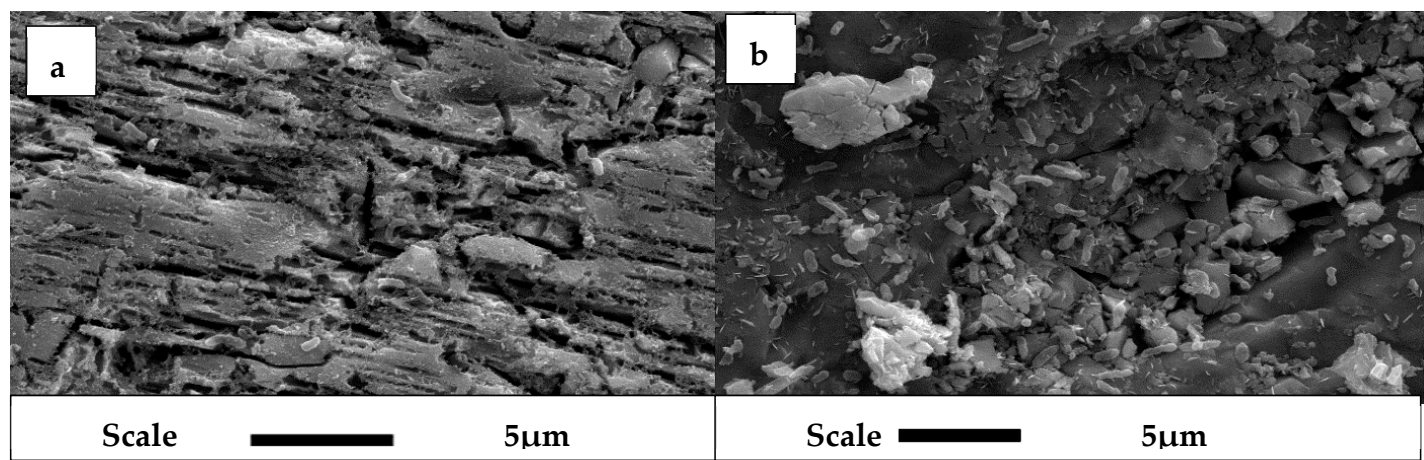

Figure 4. SEM image of (a) bacterial attachment to Py (1200× magnification) and (b) Cp (1000× magnification) at $168 \mathrm{~h}$ exposure to L.f.

The images shown in Figures 2-4 exhibit bacterial attachment on both Py and Cp surfaces with reference to exposure time. Attachment to the Py surface occurs quite readily after inoculation with rapid growth on the surface over time, creating voids in the surface, leading to an overall increase in the surface roughness. The pitting observed on the surface of Py after bacterial exposure is greater than the pitting observed when exposed to just HH media. It is seen that biofilm/EPS formation starts to form between 24 and $48 \mathrm{~h}$ exposure, with substantial biofilm observed at $48 \mathrm{~h}$. Bacterial attachment to the surface of $\mathrm{Cp}$ is not visible until $168 \mathrm{~h}$ exposure, although there is surface roughening due to the presence of precipitated salts and some dissolution observed throughout all samples. This suggests 
that surface roughness is not the primary determinant for bacterial attachment, and that pitting occurs only after bacterial attachment.

These results indicate the preferential attachment of $L . f$ to Py over Cp. Preferential attachment occurs between $0 \mathrm{~h}$ exposure and $168 \mathrm{~h}$ exposure, with bacterial cell size staying constant between cultures. Therefore, exposure times of 24,48 , and $72 \mathrm{~h}$ were selected as optimal conditioning times for bio-flotation tests. The results also indicate that EPS/biofilm formation is observed on the Py surface throughout all exposure times, while it is not observed on the chalcopyrite surface. Previous studies have investigated the adhesion of cells to solid surfaces through counts to quantify the change in cell concentration on the surface $[14,15,36]$. Visualisation of the cells on the mineral surface allows for quantification of irreversibly bound cells that are actively part of the biofilm matrix rather than physisorbed and inactive/dead/lysed cells.

Table 2 represents an approximation of cell concentration on the surface of the mineral. When compared to the growth curves in Figure 1b, the approximate cell concentration follows a similar trend to the cell concentration in the culture, reaching $1.3 \times 10^{7}$ cells $/ \mathrm{mm}^{2}$ on the surface by $168 \mathrm{~h}$ of exposure.

Table 2. Approximate cell concentration on mineral surface.

\begin{tabular}{ccc}
\hline Exposure Time (h) & Pyrite (cells/mm ${ }^{\mathbf{2}}$ ) & Chalcopyrite (cells/mm $\left.\mathbf{m m}^{\mathbf{2}}\right)$ \\
\hline 2 & $1.5 \times 10^{6} \pm 0.04 \times 10^{6}$ & 0.0 \\
24 & $3.8 \times 10^{6} \pm 0.13 \times 10^{6}$ & 0.0 \\
48 & $3.9 \times 10^{6} \pm 0.19 \times 10^{6}$ & 0.0 \\
72 & $4.0 \times 10^{6} \pm 0.16 \times 10^{6}$ & 0.0 \\
168 & $1.3 \times 10^{7} \pm 0.65 \times 10^{6}$ & $1.6 \times 10^{6} \pm 0.03$ \\
\hline
\end{tabular}

\subsection{Microflotation Tests}

Control flotation tests were conducted at $0 \mathrm{~h}$ exposure for $\mathrm{HH}$ media and M.Q. Cp recovery for control flotation tests were $26.4 \%$ for $\mathrm{HH}$ media and $3.4 \%$ for M.Q, while Py recovery was less than $3.5 \%$ and $2.6 \%$, respectively. These results indicate that $\mathrm{HH}$ media has a greater separation efficiency than M.Q. Single mineral recoveries were calculated as a percent of the recovered mineral to the starting mass of the individual mineral sample. The addition of the PIPX collector is expected to absorb to the surface of the sulfide minerals through chemical interactions between the polar groups of the collector and the copper ions on the surface [1]. This interaction produces an insoluble metal, xanthate, which renders the surface hydrophobic [1].

\subsubsection{Baseline Flotation Tests}

The mineral recovery of the baseline flotation tests at exposure times of 24,48 , and $72 \mathrm{~h}$ are shown in Figure 5. Surface oxidation of pyrite and chalcopyrite produces iron hydroxides that are more soluble at lower $\mathrm{pH}$ than higher $\mathrm{pH}$ [3]. It is expected that recovery is greater in $\mathrm{HH}$ media than M.Q. The results indicate that both minerals are more hydrophobic at the lower $\mathrm{pH}$, implying the presence of iron hydroxides at the surface. The Py recovery was noted to decrease with the increase in exposure time. Addition of the PIPX collector increases the recovery of both minerals in both $\mathrm{HH}$ media and M.Q, suggesting that copper activation of pyrite [3,39]. The separation obtained from $\mathrm{HH}$ media at $48 \mathrm{~h}$, with a $\mathrm{Cp}$ recovery of $83.4 \%$ and Py recovery of $21 \%$ is the best collectorless separation. The addition of the PIPX collector to $\mathrm{HH}$ media at $48 \mathrm{~h}$ increased the $\mathrm{Cp}$ recovery to $95.2 \%$ and Py recovery to $68.6 \%$, resulting in an overall decrease in the separation efficiency. The addition of the PIPX collector to M.Q baseline flotation tests resulted in a Cp recovery of $87 \%$ and $90.2 \%$ at 24 and $48 \mathrm{~h}$, respectively. These exposures gave the best separation efficiency as Py recovery was only $8.2 \%$ and $5.2 \%$, respectively. At $72 \mathrm{~h}$ exposure, copper activation of Py is apparent with a recovery of $86.7 \%$ and 
$\mathrm{Cp}$ recovery of only $0.5 \%$. The greatest separation efficiency with adequate $\mathrm{Cp}$ recovery is observed for M.Q in the presence of PIPX at 24 and $48 \mathrm{~h}$.



Figure 5. Baseline recoveries of $\mathrm{Cp}$ and $\mathrm{Py}$ as a function of time.

\subsubsection{The Effect of L.f Growth Conditions on Recovery}

Flotation recoveries of pyrite and chalcopyrite as a function of cell growth conditions after 24, 48, and $72 \mathrm{~h}$ of exposure to mineral, are shown in Figure 6a,b. The introduction of L.f cells and their metabolites impact on both the recovery and separation efficiency of $\mathrm{Cp}$ and Py, as shown in Figure 6a. The introduction of L.f significantly depresses the flotation of pyrite in all growth conditions in comparison to the $\mathrm{HH}$ media controls and the $\mathrm{pH} 9$ baseline tests (Table 3), while the recovery of $\mathrm{Cp}$ was variable over conditioning time and growth conditions.

The recovery of both $\mathrm{Cp}$ and Py decreases with increasing exposure to L.f grown in HH media (Figure 6a). L.f grown on Py has a greater recovery of $\mathrm{Cp}$ and Py at $48 \mathrm{~h}$, with both 24 and $72 \mathrm{~h}$ showing a loss in recovery of both minerals. In comparison to the $\mathrm{HH}$ media baseline flotation tests, there is a significant drop in $\mathrm{Cp}$ recovery over all exposure times upon the addition of the cells grown on Py. Flotation tests carried out with L.f grown on Cp have moderate recovery of Cp with increasing exposure time to $54.6 \%$ at $48 \mathrm{~h}$. Pyrite is well depressed throughout in the first $48 \mathrm{~h}$, decreasing to less than $1 \%$ at $72 \mathrm{~h}$.

The addition of the PIPX collector to flotation tests carried out with L.f on HH media increases the recovery of Cp over exposure time (Figure $6 b$ ). This is the opposite to what was observed for collectorless flotation tests, where $\mathrm{Cp}$ and Py recovery was decreased at $24 \mathrm{~h}$ by $27 \%$ and $13 \%$, respectively. The presence of cells did not inhibit the adsorption of PIPX. In this case, the cells have been grown with liquid ferrous sulfate as a food source rather than mineral and may be less efficient at mineral surface attachment. Py is depressed in the presence of $L . f$ and its metabolites under all growth conditions as compared to the HH media controls with PIPX. In particular, when the L.f cells were grown on Py, the Py recovery is suppressed to less than $1.5 \%$ for all exposure times. This may indicate the preferential attachment of L.f grown on Py to the Py particles. The addition of the PIPX collector to L.f grown on Cp reversed the outcome which was observed in the collectorless flotation tests. Both the $24 \mathrm{~h}$ and $48 \mathrm{~h}$ exposure times resulted in a greater recovery of Py and a reduced recovery of $\mathrm{Cp}$. In comparison to the $\mathrm{HH}$ media baseline, the $\mathrm{Cp}$ and Py recovery is decreased in the presence of cells grown on Cp, both in the presence of PIPX collector and as collectorless flotation. 
The best $\mathrm{Cp}$ recovery and separation efficiency was obtained from L.f grown on $\mathrm{Cp}$ with the PIPX collector $72 \mathrm{~h}$, L.f grown on HH media with PIPX collector at $48 \mathrm{~h}$, and L.f grown on Cp $48 \mathrm{~h}$. These results suggest that L.f cells and their metabolites suppress Py recovery under all growth conditions. However, $\mathrm{Cp}$ is depressed in the presence of cells.
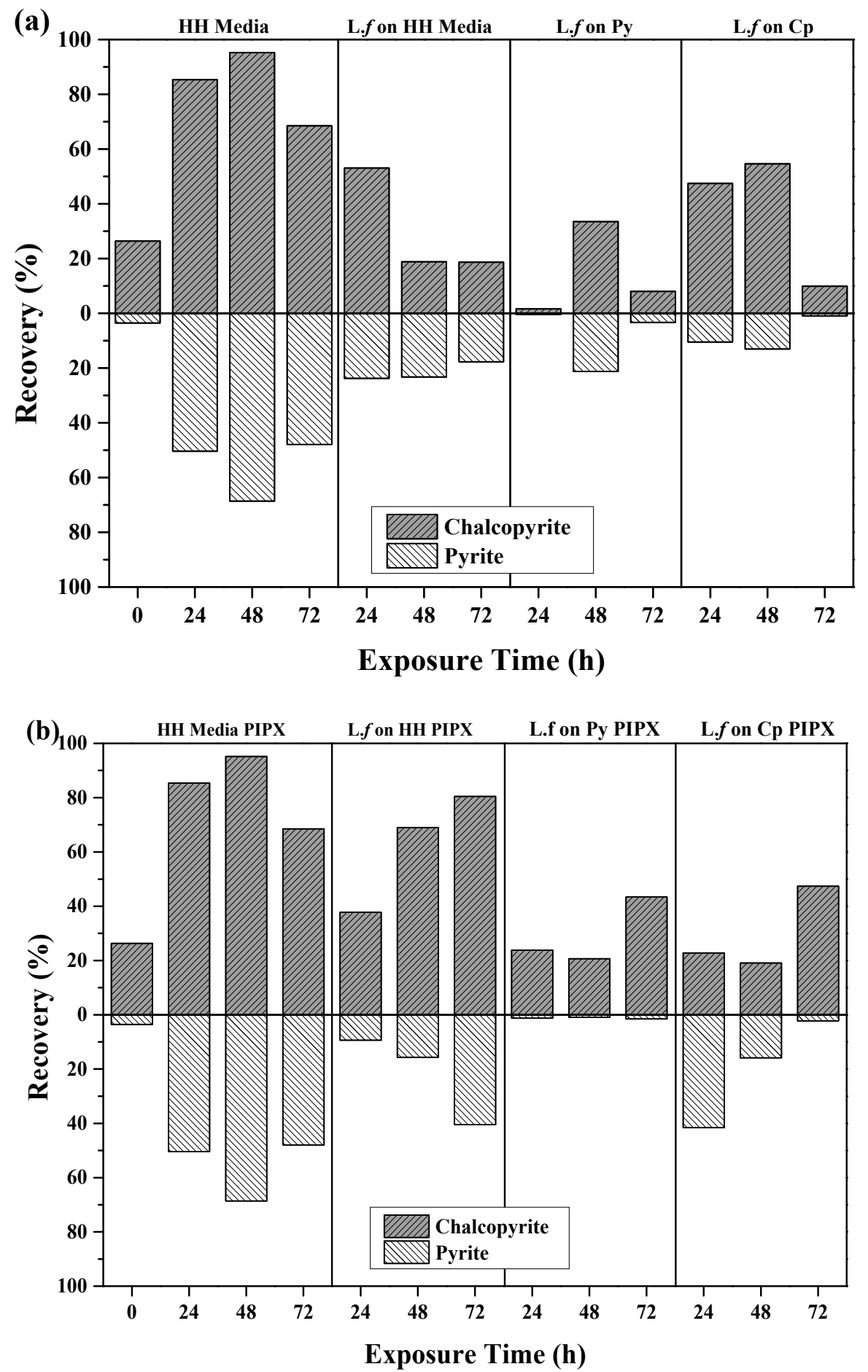

Figure 6. Recovery of $\mathrm{Cp}$ and $\mathrm{Py}$ as a function of growth conditions. (a) Collectorless flotation tests and (b) in the presence of PIPX collector. 
Table 3. Comparison of bio-flotation tests as a function of wt \% recovered for growth, EPS, and PIPX. Standard deviation was less than 0.15 for all tests.

\begin{tabular}{|c|c|c|c|}
\hline Exposure Condition & Exposure Time (h) & $\mathrm{Cp}(\%)$ & Py $(\%)$ \\
\hline \multirow{4}{*}{ HH Media } & 0 & 26.4 & 3.55 \\
\hline & 24 & 72.3 & 29.2 \\
\hline & 48 & 83.5 & 21.4 \\
\hline & 72 & 56.4 & 13.2 \\
\hline \multirow{3}{*}{ HH Media PIPX } & 24 & 85.3 & 50.4 \\
\hline & 48 & 95.2 & 68.7 \\
\hline & 72 & 68.5 & 48.0 \\
\hline \multirow{3}{*}{ M.Q pH 9 PIPX } & 24 & 87.6 & 8.2 \\
\hline & 48 & 90.2 & 5.3 \\
\hline & 72 & 0.56 & 86.7 \\
\hline \multirow{3}{*}{ L.f grown in HH Media $\left(\mathrm{Fe}^{2+}\right)$ PIPX } & 24 & 37.7 & 9.4 \\
\hline & 48 & 69.0 & 15.6 \\
\hline & 72 & 80.4 & 40.5 \\
\hline \multirow{3}{*}{ L.f grown on Py PIPX } & 24 & 23.8 & 1.2 \\
\hline & 48 & 20.7 & 0.9 \\
\hline & 72 & 43.4 & 1.5 \\
\hline \multirow{3}{*}{ L.f grown on Cp PIPX } & 24 & 22.8 & 41.6 \\
\hline & 48 & 19.1 & 15.9 \\
\hline & 72 & 47.4 & 2.3 \\
\hline \multirow{3}{*}{$\begin{array}{l}\text { EPS supernatant extracted from L.f } \\
\text { grown on Py PIPX }\end{array}$} & 24 & 79.7 & 30.5 \\
\hline & 48 & 79.4 & 29.4 \\
\hline & 72 & 74.7 & 18.9 \\
\hline \multirow{3}{*}{$\begin{array}{l}\text { EPS supernatant extracted from L.f } \\
\text { grown on Cp PIPX }\end{array}$} & 24 & 89.3 & 55.2 \\
\hline & 48 & 95.8 & 20.7 \\
\hline & 72 & 48.9 & 5.5 \\
\hline
\end{tabular}

\subsubsection{The Effect of EPS on Recovery}

The free EPS supernatant (EPS) from mineral-grown cultures was used in flotation tests to investigate the effects of EPS on the surface chemistry and separation of $\mathrm{Cp}$ and Py (Figure 7). Collectorless flotation tests using EPS from L.f grown on Py showed a decrease in recovery of both minerals as compared to the $\mathrm{HH}$ media controls (Figure 7a). The recovery of pyrite is noticeably increased in the absence of EPS. This indicates that the EPS itself has a depressive effect on the mineral, which is greater on Py than Cp. This is also supported by the results of the EPS from L.f grown on Cp flotation tests, where Py recovery remains below $1 \%$ throughout all exposure times and $\mathrm{Cp}$ recovery increases with exposure time. At 48 and $72 \mathrm{~h}$, Cp recovery increased by $49 \%$ and $65 \%$, respectively.

L.f cells removed from the culture were studied to investigate the roles both the cell and EPS play. The results show that using cells alone depresses both Py and Cp compared to the HH media controls and the extracted EPS grown on Py or Cp. There is no selectivity and the Py is not depressed as efficiently as with EPS alone. Gram-negative bacteria such as L.f. are known to have hydrophilic polysaccharides on their cell walls, however it does not provide the selectivity and efficiency that free EPS extracted from $\mathrm{Cp}$ does.

The addition of the PIPX collector increased both $\mathrm{Cp}$ and Py recovery for all conditions and exposure times in comparison to both controls and collectorless flotation tests (Figure 7b; Table 3). The PIPX collector combined with EPS from L.f. culture grown on Py increased the recovery of both $\mathrm{Cp}$ and Py, with an increase in exposure time giving a $\mathrm{Cp}$ recovery between $74.7 \%(72 \mathrm{~h})$ and $79.7 \%$ ( $24 \mathrm{~h}$ ), and Py recovery between 18.9\% (72 h) and 30.5\% (24 h). EPS from L.f. grown on Cp provided $\mathrm{Cu}$ recoveries of $89.3 \%$ and $95.8 \%$ after 24 and $48 \mathrm{~h}$, respectively. The addition of the PIPX collector increased the Py recovery to greater than that observed in all collectorless flotation tests. This indicates 
that the exposure time to EPS supernatant is correlated to the decrease in Py recovery, suggesting possible selectivity of the EPS.

Overall, L.f grown on Cp and EPS supernatant from L.f on Cp demonstrates the high recoveries and separation efficiencies with and without the presence of PIPX collector. The L.f grown on Cp and the L.f grown on Cp EPS conditions produce separation efficiencies that are on par if not greater than the baseline conditions.
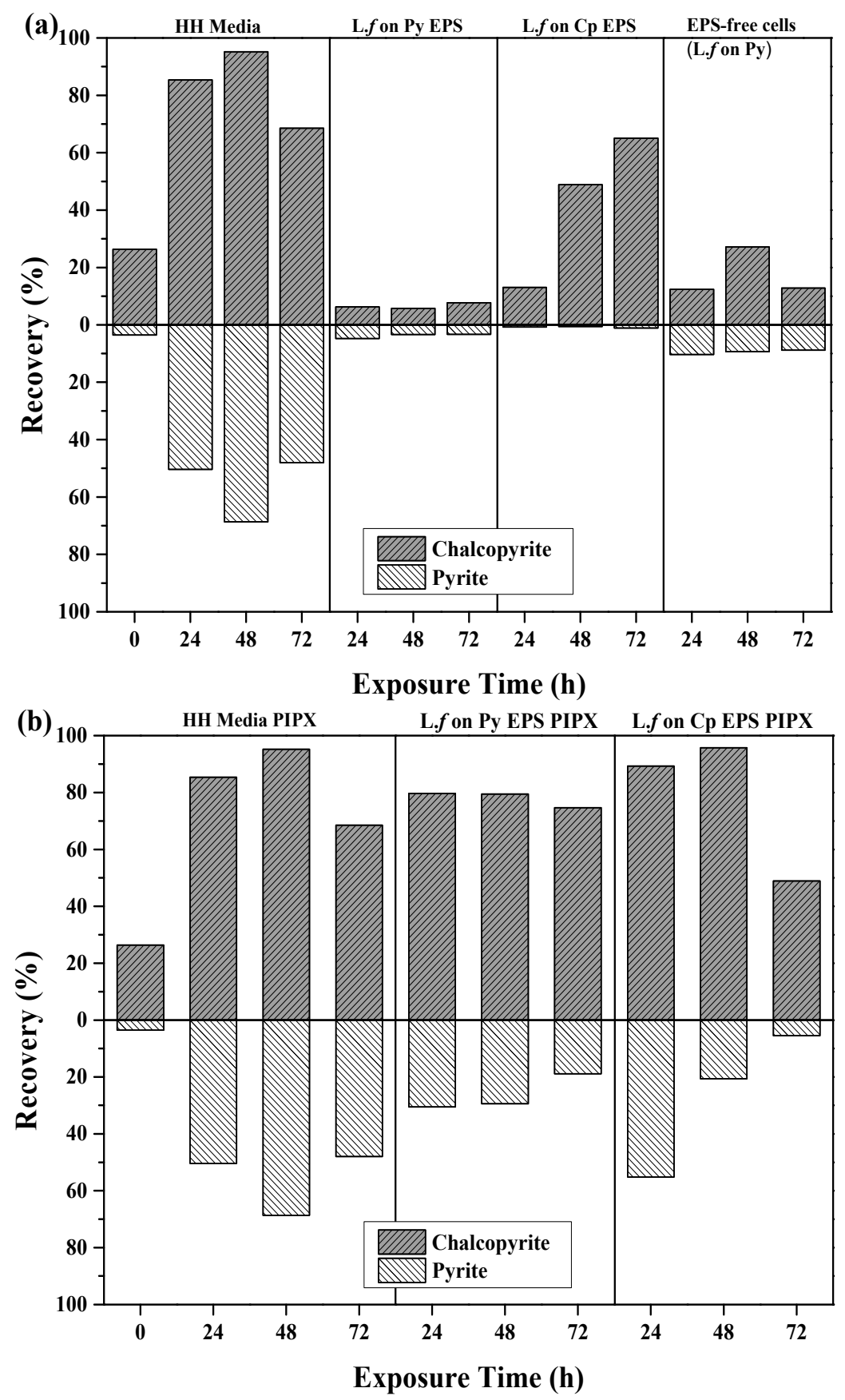

Figure 7. Recovery of $\mathrm{Cp}$ and Py using extracted EPS supernatant; (a) collectorless flotation tests and (b) in the presence of PIPX collector. 


\section{Discussion}

The growth and activity of the L.f culture is limited by the availability of ferrous iron for the cell [32]. The change in availability of the ferrous iron between the cultures grown on mineral has a significant decrease in total cell concentration for chalcopyrite growth. The HH media contains a greater amount of readily available ferrous iron than the mineral cultures. As iron exists as $\mathrm{Fe}^{\mathrm{II}}$ in $\mathrm{Py}$ and $\mathrm{Fe}^{\mathrm{III}}$ in Cp [34,35], it is expected that the L.f adapts faster to Py than Cp.

Selective attachment of L.f cells to the Py surface over Cp has been confirmed by SEM and EDAX. The SEM micrographs provide visualization of cells on the Py surface at $2 \mathrm{~h}$ after inoculation, with the approximate cells $/ \mathrm{mm}^{2}$ increasing with exposure time and following a similar trend to the culture's growth curve. Selective attachment of cells to the Py surface agrees with previous studies that found L.f to have a greater affinity to Py surfaces than their mesophilic bio-leach counterparts [12,31]. The selective attachment of L.f to Py over Cp contradicts the results found in the study by Vilinska and Rao [36], who indicated that the L. $f$ has a greater affinity to Cp than Py. However, their conclusion was determined by the change in cell concentration in solution using a Neubauer chamber, and not through visualization of the bacteria attached to the mineral surface.

Early EPS/biofilm formation was visualized on the Py surface from $48 \mathrm{~h}$ and onwards, while it was absent in all Cp samples, as observed by SEM. As bacterial attachment is facilitated by EPS [20,25], the absence of EPS on the Cp samples explains the lag in cell attachment. Likewise, the early formation of EPS on the Py samples enables the rapid increase in cell density. It is suggested that the selectivity of the cells arises from the low availability of ferrous ions and possible $\mathrm{Cu}$ toxicity [44]. The pitting observed on the bacteria-exposed Py surface was not present at the same capacity on the HH media control, indicating that the pitting was bacterially induced. A study discussed by Crundwell [45] suggests that the shape of the cross section can indicate the difference between chemical and bacterial leaching. The pitting observed in this study is cylindrical rather than hexagonal, indicating that the leaching of the surface is more than chemical leaching. This strengthens the argument that selective attachment is mediated by EPS, supporting the indirect contact mechanism.

Selective attachment occurs between inoculation at $0 \mathrm{~h}$ and $168 \mathrm{~h}$, and formation of biofilm occurs at around $48 \mathrm{~h}$. The optimal exposure times for flotation tests were determined to be 24,48 , and $72 \mathrm{~h}$. Py recovery was greatest at $72 \mathrm{~h}$ exposure in M.Q pH 9 in the presence of a PIPX collector, with a recovery of $86.7 \%$. Oxidation of pyrite results in significant amounts of elemental sulfur which is known to be hydrophobic [25]. Baseline flotation tests conducted at $72 \mathrm{~h}$ did not produce a high Py recovery, thus it is unlikely that the increase in recovery was caused through the presence of elemental sulfur from oxidation alone. As dissolution of the minerals would have started to occur by this time, copper activation of the Py is also possible [3,39]. The oxidation of Cp may have caused the formation of a passivation layer, hindering the attachment of the PIPX collector and suppressing its recovery [46].

Flotation tests conducted using cultures from different growth conditions confirm that growth conditions have a significant effect on separation efficiency. In collectorless flotation tests, L.f grown on $\mathrm{Cp}$ suppresses Py flotation while obtaining a reasonable recovery of $\mathrm{Cp}$, thus providing the best overall separation efficiency. In the presence of a PIPX collector, L. $f$ grown on Py gives the best Py suppression, while L.f grown on $\mathrm{HH}$ media results in the best chalcopyrite recovery. This is different to what was observed by Vilinska and Rao [36], who observed a greater recovery of Py than Cp. As the study by Vilinska and Rao [36] only comprised flotation tests with L.f grown on modified Leptospirillum $\mathrm{HH}$ media in the presence of a PIPX collector, it is difficult to make a direct comparison to the results of $L . f$ grown on mineral.

The decrease in mineral recovery in the presence of cells supports the findings in the studies conducted by Vilinska and Rao [36] and Chandraprabha and Natarajan [2]. A comparison of L.f cells with EPS grown on mineral to the EPS supernatant suggests that the depressive effect on Py is greater in the absence of the L.f cells. The flotation behaviour differs significantly if the EPS supernatant was extracted from cultures grown on Py or Cp. As the source of the L.f for both cultures is the same, it is 
suggested that the variation arises from the composition of the EPS. Increased depression of Py by EPS supernatant from L.f grown on Cp suggests that the EPS contains more polysaccharides than the EPS produced by L.f grown on Py [7]. By compositional analysis of EPS and determination of the key components important to sulfide mineral surface alteration, the growth conditions can be tailored to produce an adequate substitution for currently used chemicals.

\section{Conclusions}

L.f adapts to Py more effectively than $\mathrm{Cp}$, and exhibits selective attachment to Py over $\mathrm{Cp}$ between 0 and $168 \mathrm{~h}$. The interaction between $L . f$ and pyrite occurs via an indirect contact mechanism whereby metabolic products including EPS adsorb and react with the surface, resulting in irreversible cell attachment by $2 \mathrm{~h}$ exposure. Altering the growth conditions of the L.f alters the cell and EPS metabolic products which directly impacts the outcome of the flotation tests. The best separation and recovery is obtained using L.f grown on Cp and the EPS supernatant from L.f grown on Cp. The addition of a collector increases the separation efficiency, as L.f grown on Py with PIPX collector and L.f grown on Cp EPS supernatant with PIPX collector also exhibited good separation efficiency. Flotation test results indicate that the presence of $L . f$ cells has a depressive effect on both minerals, while the presence of only EPS indicates a greater separation through selective suppression of Py under acidic conditions.

Acknowledgments: The authors acknowledge the facilities, and the scientific and technical assistance of Adelaide Microscopy at the University of Adelaide, an AMMRF facility for the microscopy and microanalysis services that were accessed as part of this study. This work was funded by the Australian Research Council through FT110100099.

Author Contributions: Belinda Bleeze and Sarah Harmer conceived and designed the experiments; Belinda Bleeze performed the experiments; Belinda Bleeze and Sarah Harmer analyzed the data; Jing Zhao contributed analysis tools and software; Belinda Bleeze and Sarah Harmer wrote the paper.

Conflicts of Interest: The authors declare no conflicts of interest. The founding sponsors had no role in the design of the study; in the collection, analyses, or interpretation of data; in the writing of the manuscript, and in the decision to publish the results.

\section{References}

1. Wills, B.A. Wills' Mineral Processing Technology: An Introduction to the Practical Aspects of Ore Treatment and Mineral Recovery; Butterworth-Heinemann: Oxford, UK, 2011.

2. Chandraprabha, M.; Natarajan, K. Surface chemical and flotation behaviour of chalcopyrite and pyrite in the presence of Acidithiobacillus thiooxidans. Hydrometallurgy 2006, 83, 146-152. [CrossRef]

3. Chandraprabha, M.; Natarajan, K.; Modak, J.M. Selective separation of pyrite and chalcopyrite by biomodulation. Colloids Surf. B Biointerfaces 2004, 37, 93-100. [CrossRef] [PubMed]

4. Partha, P.; Natarajan, K. Microbially enhanced removal of pyrite and chalcopyrite from oxide gangue minerals with reference to desulfurization of tailings. Miner. Metall. Process. 2004, 21, 169-178.

5. Dwyer, R.; Bruckard, W.; Rea, S.; Holmes, R. Bioflotation and bioflocculation review: Microorganisms relevant for mineral beneficiation. Miner. Process. Extr. Metall. 2012, 121, 65-71. [CrossRef]

6. Haferburg, G.; Kothe, E. Microbes and metals: Interactions in the environment. J. Basic Microbiol. 2007, 47, 453-467. [CrossRef] [PubMed]

7. Govender, Y.; Gericke, M. Extracellular polymeric substances (EPS) from bioleaching systems and its application in bioflotation. Miner. Eng. 2011, 24, 1122-1127. [CrossRef]

8. Deo, N.; Natarajan, K. Interaction of Bacillus polymyxa with some oxide minerals with reference to mineral beneficiation and environmental control. Miner. Eng. 1997, 10, 1339-1354. [CrossRef]

9. Chandraprabha, M.; Natarajan, K.; Somasundaran, P. Selective separation of arsenopyrite from pyrite by biomodulation in the presence of Acidithiobacillus ferrooxidans. J. Colloid Interface Sci. 2004, 276, 323-332. [CrossRef] [PubMed]

10. Subramanian, S.; Santhiya, D.; Natarajan, K. Surface modification studies on sulphide minerals using bioreagents. Int. J. Miner. Process. 2003, 72, 175-188. [CrossRef] 
11. Harneit, K.; Göksel, A.; Kock, D.; Klock, J.-H.; Gehrke, T.; Sand, W. Adhesion to metal sulfide surfaces by cells of Acidithiobacillus ferrooxidans, Acidithiobacillus thiooxidans and Leptospirillum ferrooxidans. Hydrometallurgy 2006, 83, 245-254. [CrossRef]

12. Zhu, J.; Li, Q.; Jiao, W.; Jiang, H.; Sand, W.; Xia, J.; Liu, X.; Qin, W.; Qiu, G.; Hu, Y. Adhesion forces between cells of Acidithiobacillus ferrooxidans, Acidithiobacillus thiooxidans or Leptospirillum ferrooxidans and chalcopyrite. Colloids Surf. B Biointerfaces 2012, 94, 95-100. [CrossRef] [PubMed]

13. Lavalle, L.; Giaveno, A.; Pogliani, C.; Donati, E. Bioleaching of a polymetallic sulphide mineral by native strains of Leptospirillum ferrooxidans from Patagonia Argentina. Process Biochem. 2008, 43, 445-450. [CrossRef]

14. Kim, G.; Park, K.; Choi, J.; Gomez-Flores, A.; Han, Y.; Choi, S.Q.; Kim, H. Bioflotation of malachite using different growth phases of Rhodococcus opacus: Effect of bacterial shape on detachment by shear flow. Int. J. Miner. Process. 2015, 143, 98-104. [CrossRef]

15. Kim, H.N.; Hong, Y.; Lee, I.; Bradford, S.A.; Walker, S.L. Surface characteristics and adhesion behavior of Escherichia coli O157:H7: Role of extracellular macromolecules. Biomacromolecules 2009, 10, 2556-2564. [CrossRef] [PubMed]

16. Rao, K.H.; Vilinska, A.; Chernyshova, I. Minerals bioprocessing: R \& D needs in mineral biobeneficiation. Hydrometallurgy 2010, 104, 465-470.

17. Sand, W.; Gerke, T.; Hallmann, R.; Schippers, A. Sulfur chemistry, biofilm, and the (in) direct attack mechanism-A critical evaluation of bacterial leaching. Appl. Microbiol. Biotechnol. 1995, 43, 961-966. [CrossRef]

18. He, Z.-G.; Yang, Y.-P.; Shan, Z.; Hu, Y.-H.; Zhong, H. Effect of pyrite, elemental sulfur and ferrous ions on eps production by metal sulfide bioleaching microbes. Trans. Nonferrous Met. Soc. China 2014, 24, 1171-1178. [CrossRef]

19. Hosseini, T.; Kolahdoozan, M.; Tabatabaei, Y.; Oliazadeh, M.; Noaparast, M.; Eslami, A.; Manafi, Z.; Alfantazi, A. Bioflotation of sarcheshmeh copper ore using Thiobacillus ferrooxidans bacteria. Miner. Eng. 2005, 18, 371-374. [CrossRef]

20. Sand, W.; Gehrke, T. Extracellular polymeric substances mediate bioleaching/biocorrosion via interfacial processes involving iron(iii) ions and acidophilic bacteria. Res. Microbiol. 2006, 157, 49-56. [CrossRef] [PubMed]

21. Flemming, H.-C.; Neu, T.R.; Wozniak, D.J. The EPS matrix: The "House of biofilm cells". J. Bacteriol. 2007, 189, 7945-7947. [CrossRef] [PubMed]

22. Jiao, Y.; Cody, G.D.; Harding, A.K.; Wilmes, P.; Schrenk, M.; Wheeler, K.E.; Banfield, J.F.; Thelen, M.P. Characterization of extracellular polymeric substances from acidophilic microbial biofilms. Appl. Environ. Microbiol. 2010, 76, 2916-2922. [CrossRef] [PubMed]

23. He, H.; Xia, J.-L.; Hong, F.-F.; Tao, X.-X.; Leng, Y.-W.; Zhao, Y.-D. Analysis of sulfur speciation on chalcopyrite surface bioleached with Acidithiobacillus ferrooxidans. Miner. Eng. 2012, 27, 60-64. [CrossRef]

24. Gehrke, T.; Telegdi, J.; Thierry, D.; Sand, W. Importance of extracellular polymeric substances from Thiobacillus ferrooxidans for bioleaching. Appl. Environ. Microbiol. 1998, 64, 2743-2747. [PubMed]

25. Rohwerder, T.; Sand, W. Mechanisms and Biochemical Fundamentals of Bacterial Metal Sulfide Oxidation. In Microbial Processing of Metal Sulfides; Springer: Berlin, Germany, 2007; pp. 35-58.

26. Sharma, P.; Das, A.; Rao, K.H.; Forssberg, K. Surface characterization of Acidithiobacillus ferrooxidans cells grown under different conditions. Hydrometallurgy 2003, 71, 285-292. [CrossRef]

27. Kim, H.N.; Walker, S.L.; Bradford, S.A. Macromolecule mediated transport and retention of Escherichia coli O157:H7 in saturated porous media. Water Res. 2010, 44, 1082-1093. [CrossRef] [PubMed]

28. Liu, Q.; Zhang, Y.; Laskowski, J.S. The adsorption of polysaccharides onto mineral surfaces: An acid/base interaction. Int. J. Miner. Process. 2000, 60, 229-245. [CrossRef]

29. Schippers, A.; Jozsa, P.; Sand, W. Sulfur chemistry in bacterial leaching of pyrite. Appl. Environ. Microbiol. 1996, 62, 3424-3431. [PubMed]

30. Olson, G.J. Rate of pyrite bioleaching by Thiobacillus ferrooxidans: Results of an interlaboratory comparison. Appl. Environ. Microbiol. 1991, 57, 642-644. [PubMed]

31. Sand, W.; Rohde, K.; Sobotke, B.; Zenneck, C. Evaluation of Leptospirillum ferrooxidans for leaching. Appl. Environ. Microbiol. 1992, 58, 85-92. [PubMed]

32. Ohmura, N.; Kitamura, K.; Saiki, H. Mechanism of microbial flotation using Thiobacillus ferrooxidans for pyrite suppression. Biotechnol. Bioeng. 1993, 41, 671-676. [CrossRef] [PubMed] 
33. Pecina, E.; Rodriguez, M.; Castillo, P.; Diaz, V.; Orrantia, E. Effect of Leptospirillum ferrooxidans on the flotation kinetics of sulphide ores. Miner. Eng. 2009, 22, 462-468. [CrossRef]

34. Goh, S.W.; Buckley, A.N.; Lamb, R.N.; Rosenberg, R.A.; Moran, D. The oxidation states of copper and iron in mineral sulfides, and the oxides formed on initial exposure of chalcopyrite and bornite to air. Geochim. Cosmochim. Acta 2006, 70, 2210-2228. [CrossRef]

35. Pearce, C.I.; Pattrick, R.A.D.; Vaughan, D.J.; Henderson, C.M.B.; van der Laan, G. Copper oxidation state in chalcopyrite: Mixed cu d9 and d10 characteristics. Geochim. Cosmochim. Acta 2006, 70, 4635-4642. [CrossRef]

36. Vilinska, A.; Rao, K.H. Leptosririllum ferrooxidans-sulfide mineral interactions with reference to bioflotation nad bioflocculation. Trans. Nonferrous Met. Soc. China 2008, 18, 1403-1409. [CrossRef]

37. Kalegowda, Y.; Chan, Y.-L.; Wei, D.-H.; Harmer, S.L. X-PEEM, XPS and ToF-SIMS characterisation of xanthate induced chalcopyrite flotation: Effect of pulp potential. Surf. Sci. 2015, 635, 70-77. [CrossRef]

38. Bastías, M.; Gentina, J. Variables affecting the growth and ferrous oxidation capacity of L. Ferrooxidans in continuous culture. Hydrometallurgy 2010, 104, 351-355.

39. Khmeleva, T.N.; Beattie, D.A.; Georgiev, T.V.; Skinner, W.M. Surface study of the effect of sulphite ions on copper-activated pyrite pre-treated with xanthate. Miner. Eng. 2003, 16, 601-608. [CrossRef]

40. Houot, R.; Duhamet, D. Floatability of chalcopyrite in the presence of dialkyl-thionocarbamate and sodium sulfite. Int. J. Miner. Process. 1993, 37, 273-282. [CrossRef]

41. Coelho, A. TOPAS Academic: General Profile and Structure Analysis Software for Powder Diffraction Data; Bruker AXS: Karlsruhe, Germany, 2007.

42. Orell, A.; Navarro, C.A.; Arancibia, R.; Mobarec, J.C.; Jerez, C.A. Life in blue: Copper resistance mechanisms of bacteria and archaea used in industrial biomining of minerals. Biotechnol. Adv. 2010, 28, 839-848. [CrossRef] [PubMed]

43. Usher, K.; Shaw, J.; Kaksonen, A.; Saunders, M. Elemental analysis of extracellular polymeric substances and granules in chalcopyrite bioleaching microbes. Hydrometallurgy 2010, 104, 376-381. [CrossRef]

44. Rojas-Chapana, J.A.; Tributsch, H. Interfacial activity and leaching patterns of Leptospirillum ferrooxidans on pyrite. FEMS Microbiol. Ecol. 2004, 47, 19-29. [CrossRef]

45. Crundwell, F. How do bacteria interact with minerals? Hydrometallurgy 2003, 71, 75-81. [CrossRef]

46. Bevilaqua, D.; Lahti-Tommila, H.; Garcia, O., Jr.; Puhakka, J.A.; Tuovinen, O.H. Bacterial and chemical leaching of chalcopyrite concentrates as affected by the redox potential and ferric/ferrous iron ratio at $22{ }^{\circ} \mathrm{C}$. Int. J. Miner. Process. 2014, 132, 1-7. [CrossRef] 